\title{
Proceedings of the Special General Meeting, 2018
}

The 116th Annual General Meeting (AGM) of The Southern African Institute of Mining and Metallurgy (SAIMM) was held at The Country Club, Johannesburg, Napier Road, Auckland Park on Wednesday, 16 August 2018.

\section{Special General Meeting}

A Special General Meeting (SGM) of the SAIMM Council was convened to consider the proposed changes to the Constitution was held immediately prior to the AGM.

\section{Purpose}

In order for the SAIMM to remain relevant and ensure maximum value for all members, the Council proposed additional changes to and clarification of some of the clauses in the Constitution and By-law B. These were proposed at the Council meeting on Friday 18 May 2018; these changes had to be approved by means of a ballot at a SGM.

\section{Background}

In order for the SAIMM to remain relevant and ensure maximum value for all members, the amendments listed below were forwarded to all Corporate members for their consideration and approval.

\section{Conclusion}

The proposed amendments below were approved by the requisite two-thirds majority.

The Southern African Institute of Mining and Metallurgy Constitution (as amended)

\section{The Institute}

1.1 The name of the Institute is:

The Southern African Institute of Mining and Metallurgy (SAIMM), (the Institute).

\section{Membership}

2.7 The Council shall issue to every Fellow, Member and Associate a certificate showing the category to which he/she has been elected. Students shall be issued with proof of membership. A special certificate shall be issued to all Company Affiliates. Such certificates shall remain the property of, and shall on request be returned to, the Institute.

\section{Council}

3.1 Subject to the Constitution, and in accordance with the provisions of the relevant By-laws, the management and administration of the affairs of the Institute and the power to carry out the key objectives shall be vested in and exercised by the Council.
3.2 The fourteen (14) members of the Council shall be nominated, elected and/or removed annually in accordance with the provisions of the relevant Bylaws and shall hold office until their successors have been elected.

3.3 A minimum of three (3) of the fourteen (14) elected members shall be persons who are not 'connected persons', as defined in the Income Tax Act, in relation to one another.

3.4 No single person shall, directly or indirectly, control the decision-making powers of the Institute.

3.5 The Council shall consist of the following elected, invited and co-opted members:

3.5.7 The fourteen (14) elected Corporate members 3.5.8 The Chairperson or the Vice Chairperson of the Young Professionals Council (the YPC), who shall not be entitled to vote on matters concerning the policy of the SAIMM if they are not Corporate members, and who shall also represent the interests of Associate and Student members of the Institute.

3.6 The Council shall include the following ex-officio members:

3.6.1 The Chairperson of any Division established in terms of Clause 4.6.

3.6.2 The Chairperson of any Branch established in terms of Clauses 4.5 and 4.6.

3.6.3 Representatives nominated by other professional organisations with whom the Institute shares common interests, shall be invited to attend the Council meetings in an observer role.

3.7 Members of the Council, except Office Bearers, retire annually after conclusion of the AGM, but shall be eligible for re-election in the same or another capacity.

3.9 The Council may, to ensure adequate representation based on the identified needs, such as diversity, and the balance of the practice areas of mining and metallurgy, nominate, elect and co-opt not more than six (6) additional Corporate members to the Council in accordance with the provisions of By-law B. Such additional members shall have the privileges and responsibilities of elected members of the Council and shall hold office for that current session.

3.10 Should any member of the Council or the Office Bearers Committee be absent without prior approved leave from the relevant Chairperson for more than 2 (two) consecutive meetings, he/she may, at the discretion of the Council, be requested to forfeit his/her seat on the Council. 


\section{Special General Meeting and Constitution, 2018}

3.11 Should any member of the Institute have reason to lodge a complaint against another member he/she must do so by referring it to the Complaints Committee.

3.12 A member of the Council, an Office Bearer or an Official of the Institute may be removed from office:

3.12.1 Should he/she be found to infringe any of the provisions of the Constitution or any of the By-laws;

3.12.2 Should he/she act in a manner which is detrimental to the interests of the Institute.

3.13 No member of the Council, an Office Bearer, or an Official of the Institute may be removed from office unless he/she has been afforded the opportunity to state his/her case personally at a meeting of the Complaints Committee or any other appropriate manner determined after consultation with the member. This must be done within a time frame stipulated by the Complaints Committee.

3.14 A member of the Council, an Office Bearer, or an Official of the Institute who has appeared before the Complaints Committee and who is dissatisfied with the decision of the Complaints Committee shall have the right to appeal to the first ensuing meeting of the Council. Notice of appeal shall be submitted, in writing, in the prescribed format to the Manager within a period not exceeding 30 (thirty) days of the date on which the decision of the Complaints Committee was communicated to the person concerned. The decision of the Council in this regard shall be final.

3.15.1 Providing medals or other prizes as the Council may direct from time to time.

3.16 The Institute will receive the majority of its funding from conference fees, annual membership subscriptions, revenue from advertising or other fees, donations, and contributions.

3.17 The accounts of the Institute shall be audited annually by the Auditor (-s) whose appointment shall be ratified by the members present at the AGM for the ensuing year based on the recommendation of the Council. No member or official of the Institute shall be eligible for the position of Auditor. Should the Auditor position become vacant, it shall be filled by the next meeting of the incoming Council.

3.18 The Council shall submit, at each AGM, a report on the affairs of the Institute together with the audited Financial Statements as at 30 June of that year.

3.24 The Council shall meet as often as deemed necessary for the proper execution of its duties, but not fewer than four times per year. In the period between meetings, urgent decisions may be taken in a manner prescribed for this purpose by the Council.

\section{Subordinate structures}

4.1 The Council may establish Committees to perform some of the duties of the Council. Non-exclusive examples of such Committees are those for publications, event organization, membership, and young professionals.

\section{Office Bearers}

To be read in conjunction with the provisions of By-law B.

5.1 Office Bearers shall consist of:

$>$ The President

$>$ The President-Elect

$>$ The Senior Vice President

> The Junior Vice President

> The Immediate Past President

> The Honorary Treasurer

> Up to two Corporate members may be co-opted to the Office Bearers Committee.

5.2 The Council shall have the right to co-opt up to two additional Corporate members to the Office Bearers Committee if good reason to do so exists.

5.6 The Council may, as the only valid decision-making body of the Institute, delegate some or all of its powers to the Office Bearers Committee or any other subordinate structure of the Institute if such delegation of powers is considered to be in the best interests of the Institute. Any such delegation shall be valid only for the current session of the Institute or such shorter period as deemed appropriate by the Council.

\section{Meetings of the Institute}

6.2 The Annual Session of the Institute shall be from 1 July of any year to 30 June of the succeeding year. The Annual General Meetings of the Institute shall be held in August on a date decided by the Council to receive and consider the report of the Council, the audited Financial Statements, as well as the confirmation from the Auditor of the outcome of the voting process for the election of the 14 (Fourteen) members of the Council, the announcement of Clause 3.2 members of the Council and to conduct such other business as the Council may decide.

A complete and updated version of the Constitution and ByLaw B is available on the Institute's website (www.saimm.co.za).

\section{BY-LAW B}

\section{COUNCIL: ELECTION AND DUTIES}

\section{B1 DUTIES AND MEETINGS OF COUNCIL}

B1.1 Subject to 3.2.4, the Council shall meet as often as the business of the Institute requires, but not less than four times per year.

B1.2 At meetings of the Council, 12 (twelve) Corporate members of the Council present at the meeting shall constitute a quorum.

B1.3 All matters shall be decided by vote of a simple majority of Corporate members of the Council who are eligible to vote.

B1.4 The President as chairperson of the Council meetings shall have a deliberative vote and, in the event of a tied ballot, a casting vote. The President or, in his/her absence, the President Elect, or, in the 
absence of both parties, a member of the Office Bearers Committee shall take the Chair at all meetings of the Council.

B1.5 During the period between the Council meetings, urgent decisions may be taken in a manner prescribed for this purpose by the Council.

B1.6 At the request of any 3 (three) Corporate members present, any item on the agenda may be postponed until the next meeting and then shall be decided by a simple majority of members present at the meeting who are eligible to vote. The notice calling for the subsequent meeting must clearly indicate that there is a subject on the agenda that requires discussion and a decision.

B1.7 When the Council appoints Committees, such appointments and/or representatives may be made from members of the Institute or from such other persons as the Council may select to further the interests and work of the Institute. The President shall be, ex-officio, a member of all committees.

B1.8 The President or, in his/her absence, the President Elect may extend the privileges of the Institute to members of recognised professional bodies with comparable status who are visiting the Republic of South Africa.

\section{B2 NOMINATION, ELECTION, AND REMOVAL OF THE 14} ELECTED MEMBERS OF THE COUNCIL

B2.1 The Manager shall invite members of the Council not later than the first day of May in each year to submit nominations for the 14 (fourteen) elected members of the Council. Such nominations shall be lodged with the Manager not less than 60 (sixty) calendar days prior to the date of the Annual General Meeting (AGM).

B2.1.1 Only Corporate members of the Institute are eligible to be nominated as one of the 14 (fourteen) elected members of the Council;

B2.1.2 Each nomination for the 14 (fourteen) elected members of the Council must be proposed and seconded by at least 2 (two) Corporate members on the prescribed official nomination form; and

B2.1.3 The members of the Council shall be provided with the nomination criteria which apply to the 14 (fourteen) elected members of the Council.

B2.2 Upon receipt of the nominations, the Manager shall:

B2.2.1 Check that each nominee complies with the approved nomination requirements;

B2.2.2 Obtain a copy of an abridged CV per nominee, highlighting his/her contribution to the Institute; and

B2.2.3 Notify each nominee and request his/her acceptance or otherwise of such nomination within 10 (ten) calendar days. Failure by the nominee to accept such nomination will make it null and void.
B2.3 At least 30 (thirty) calendar days prior to the AGM, the Manager shall forward the respective ballot list showing the names, the qualifications, occupations and relevant contact details of eligible nominees to each of the voting members of the Council. The said ballot list shall be accompanied by an abridged $\mathrm{CV}$ per nominee.

B2.3.1 The prescribed voting process of voting for the said nominees shall take place over a period of 2 (two) weeks or longer but not later than 14 (fourteen) days prior to the AGM; and

B2.3.2 In the event of the number of votes being found to be equal for any 2 (two) or more nominees, all of whom may not be declared elected; the Office Bearers Committee shall apply the procedure to be followed to finalise a tied ballot.

B3 Should the list of nominees for 14 (fourteen) members to be elected to the Council not include the names of as many members as are required to fill the vacancies on the incoming Council, the outgoing Council shall, after scrutiny of the ballot list, nominate eligible Corporate members to complete the list and the members thus nominated shall be declared elected at the next AGM.

B4 The Council shall have the right to request a member of the Council to forfeit his/her position or to resign if there is proof of unacceptable behaviour and/or that he/she is unable to perform his/her duties.

B4.1 The Council shall discuss and agree on the process to remove a member of the Council in the absence of the affected member of the Council;

B4.2 After consultation and engagement with the affected member of the Council, a request shall be submitted for consideration and final resolution to the Council in the form of a letter setting out the reasons for the recommendation;

B4.3 The Manager shall circulate the letter to the members of the Council for their consideration, comment and/or ratification;

B4.4 Members of the Council shall be requested to approve or ratify this decision at the next Council meeting; and

B4.5 Should any position on the Council become vacant, the same process as detailed herein before shall be implemented immediately following the resignation of or forfeiture of the position of a member of the Council.

\section{B5 OFFICE BEARERS}

\section{B5.1 DUTIES AND MEETINGS OF OFFICE BEARERS}

B5.1.1 The duties of the Office Bearers Committee shall include but not be limited to:

> Assisting the President to promote the aims of the Institute;

$>$ Attending meetings of the Office Bearers Committee; 
> Formulate recommendations to the Council regarding the functioning of the Institute;

$>$ Oversee the day-to-day business of the Institute.

B5.1.2 During periods between the Council meetings, the Office Bearers Committee shall receive reports from the various Committees of the Institute on behalf of the Council and shall then report to the Council at the next meeting of the Council.

B5.1.3 The Office Bearers Committee shall meet on a monthly basis, with the exception of August, when the Council is in recess, and December.

\section{B5.2 NOMINATION, ELECTION, AND REMOVAL OF} OFFICE BEARERS

B5.2.1 The Council shall, each year at the May meeting of the Council, ratify all the positions within the Office Bearers Committee to ascertain that all Office Bearers are still willing, available, and able to fulfil the positions to which they have been elected.

B5.2.2 The Council shall have the right to request an office Bearer to forfeit his/her position or to resign if there is proof of unacceptable behaviour and/or that he/she is unable to perform his/her duties.

B5.2.3 Office Bearers shall discuss and agree on the process to remove a member of the Office Bearers Committee in the absence of the affected Office Bearer.

B5.2.4 After consultation and engagement with the affected Office Bearer, a request, in the form of a letter setting out the reasons for the recommendation, shall be submitted for consideration and finalisation to the Council.

B5.2.5 The Manager shall circulate the letter for consideration, comment and/or ratification to all members of the Council.

B5.2.6 Members of the Council shall be requested to approve or ratify this decision at the next meeting of the Council.

B5.2.7 If any position within the Office Bearers Committee becomes vacant, the same process as detailed here-in before shall be implemented immediately following the resignation/forfeiture of an Office Bearer's position.

\section{B6 NOMINATION, ELECTION, AND REMOVAL OF THE} JUNIOR VICE PRESIDENT

B6.1 The Manager shall timeously invite members of the Institute to submit nominations for the position of Junior Vice President for the next year. Such nominations shall be lodged with the Manager in writing three weeks prior to the May meeting of the Council.

B6.2 The members of the Council shall be provided with a Council-approved list of criteria to be considered when submitting the names of eligible nominees.
B6.3 The Manager shall compile a list of eligible nominees received from the members of the Council, for consideration by the Office Bearers Committee.

B6.4 The Office Bearers Committee shall apply their minds to the list and agree on the preferred candidate intended to become the Junior Vice President for the next year; the name of the candidate shall be forwarded for consideration/ratification by the Council at its May meeting.

B6.5 Once a Council member has been appointed as Junior Vice President, there shall will be an automatic annual progression from this position to Senior Vice President, President Elect, and President, subject to ratification by the Council.

B6.6 Should the position of the Junior Vice President become vacant, the Council will fill the vacancy using the process described here-in before.

B6.7 The Council shall have the right to request the Junior Vice President to forfeit his/her position or to resign if there is proof of unacceptable behaviour and/or that he/she is unable to perform his/her duties. The process used to remove a Junior Vice President is described in Clauses B5.2.4, B5.2.5 and B5.2.6.

\section{B7 NOMINATION, ELECTION, AND REMOVAL OF THE} HONORARY TREASURER

B7.1 The Honorary Treasurer shall be a Corporate member of the Council, with a working knowledge of and personal interest in finances and accounting, and who is available and willing to take on the position.

B7.2 Members of the Council shall nominate and ratify the appointment of the Honorary Treasurer on an annual basis at the May meeting of the Council.

B7.3 Should the position of Honorary Treasurer be currently filled, the Manager shall timeously request the members of the Council to ratify the appointment of the current incumbent for the next year.

B7.4 Should the position of Honorary Treasurer become vacant, the Manager shall circulate an invitation to members of the Council to submit nominations, in writing, for the position. Nominations must comply with the selection criteria, approved for this purpose by the Council.

B7.5 The Manager shall validate the nominees and confirm which nominees are eligible for the position of Honorary Treasurer.

B7.6 The list of eligible candidates shall be circulated to the Office Bearers Committee for its consideration and recommendation of the preferred candidate for consideration and finalisation by the Council at the May meeting.

B7.7 The Council shall have the right to request the Honorary Treasurer to forfeit his/her position or to resign if there is proof of unacceptable behaviour and/or that he/she is unable to perform his/her duties. The process used to remove the Honorary Treasurer is described in Clauses B5.2.4, B5.2.5 and B5.2.6.. 